\title{
Research on the Fiscal Treatment Effects of Debt Financing in Retail Industry
}

\author{
Wang Jing \\ Commercial College of Guilin University of Electronic Technology, Guilin, Guangxi, 541004 \\ hunter2011@foxmail.com
}

Keyword: Public companies in retail industry, Fscal treatment; Debt financing, The structure of debt source, The structure of debt term

\begin{abstract}
The retail industry in our country relies on current debt excessively for a long time, and the bank loan is its main financing channels at all time. At the same time, the bond financing is highlighted. Some financing way are main financing ways for retail industry in our country. For example, issuing financing invoice or convertible bonds and so on. But the creditors do not fully present the status and the role in company management. The structure of debt source and the structure of debt term are not reasonable, and the positive fiscal treatment effects of debt financing do not work fully in public companies in retail industry. We make a practical research on the fiscal treatment effects of debt financing of public companies in retail industry and reveal the problems through updated fiscal data of public companies in retail industry in the paper.

The problems resolved by the financing policy are the problems of capital source during the process of enterprise operation. It is the most critical content in fiscal activity of contemporary enterprise. Debt financing is the important fiscal decision for enterprise. We reveal the reasons that fiscal treatment of debt financing in retail industry which have not obvious effects by following example analysis in this paper.
\end{abstract}

\section{The Design of Example Research}

The Choice of Sample. We chooses the fiscal data during 2005-2014 as research sample in this paper, which are the fiscal data of public companies in The shares retail industry listed at Shenzhen or Shanghai. We eliminate the public companies like ST, ${ }^{*} \mathrm{ST}, \mathrm{S} * \mathrm{ST}$. The data used in this paper are from Xenophon database. We use the statistical software of Excel2007 and SPSS17.0 of Microsoft to get the following data processing and data statistics.

The Choice of Variables.

\begin{tabular}{|c|c|c|c|c|}
\hline \multicolumn{2}{|c|}{ Type } & Symbol & Name & Variable definition \\
\hline $\begin{array}{l}\text { depende } \\
\text { nt } \\
\text { variable }\end{array}$ & $\begin{array}{l}\text { company } \\
\text { value }\end{array}$ & ROA & $\begin{array}{l}\text { yield rate of } \\
\text { total assets }\end{array}$ & total gains $\div$ total assets \\
\hline \multirow{6}{*}{$\begin{array}{l}\text { independ } \\
\text { ent } \\
\text { variable }\end{array}$} & \multirow{2}{*}{ debt term } & $\mathrm{SD}$ & $\begin{array}{l}\text { debt rate in } \\
\text { short-term }\end{array}$ & short-term debts/ total assets \\
\hline & & LD & $\begin{array}{l}\text { debt rate in } \\
\text { long-term }\end{array}$ & long-term debts/ total assets \\
\hline & \multirow{3}{*}{ debt source } & $\mathrm{CD}$ & $\begin{array}{l}\text { the rate of } \\
\text { commercial } \\
\text { credit }\end{array}$ & $\begin{array}{l}\text { (accounts payable+deposit } \\
\text { received+notes payable)/total debts }\end{array}$ \\
\hline & & $\mathrm{BD}$ & $\begin{array}{l}\text { the rate of bank } \\
\text { loan }\end{array}$ & $\begin{array}{ll}\text { (short-term } & \text { loans }+ \text { long-term } \\
\text { loans)/total debts } & \end{array}$ \\
\hline & & BOD & $\begin{array}{l}\text { proportion of } \\
\text { enterprise bond }\end{array}$ & bonds payable/long-term loans \\
\hline & $\begin{array}{l}\text { capital } \\
\text { structure }\end{array}$ & DER & $\begin{array}{l}\text { proportion of } \\
\text { property right }\end{array}$ & total debts/total owns equity \\
\hline
\end{tabular}

The Assumptions of Research. Assumption one: The debt financing in public companies in retail industry does not play its role efficiently in fiscal treatment. One of reasons is that the structure of debt term is not reasonable. 
Assumption two: The debt financing in public companies in retail industry does not play its role efficiently in fiscal treatment. One of reasons is that the structure of debt source is not reasonable.

The Model Building. According to the analysis above, we establish regression model blew to inspect the fiscal treatment effects of debt financing in public companies in retail industry, $\mathrm{ROA}=$ $\beta 0+\beta 1 \mathrm{SDi}+\beta 2 \mathrm{LDi}+\beta 3 \mathrm{CDi}+\beta 4 \mathrm{BDi}+\beta 5 \mathrm{BODi}+\beta 6 \mathrm{DERi}+\varepsilon \mathrm{i}(\mathrm{i}=1,2 、 3 \ldots 14 ;) . \beta 0$ in this model represents constant term, and i represents company, and $\varepsilon i$ is random disturbance term.

\section{The Analysis of the Result of Example Research}

Descriptive Analysis. The Structure of Debt Term. The contents in the table below are the structure of debt term of normal public companies in public company of retail industry during 2005-2014.

Descriptive statistics

\begin{tabular}{|l|l|l|l|l|l|l|}
\hline & $\mathrm{N}$ & $\begin{array}{l}\text { Minimum } \\
\text { value }\end{array}$ & $\begin{array}{l}\text { Maximum } \\
\text { value }\end{array}$ & Mean value & $\begin{array}{l}\text { Standard } \\
\text { deviation }\end{array}$ & $\begin{array}{l}\text { Varianc } \\
\text { e }\end{array}$ \\
\hline LD & 667 & .1449860 & .8407010 & .514329114 & .1601034913 & .026 \\
SD & 667 & .0000000000 & .3415300000 & .0525460704 & .0734538374 & .005 \\
& & 000140 & 000000 & 64777 & 48403 & \\
$\begin{array}{l}\text { Effective N (list } \\
\text { state) }\end{array}$ & 667 & & & & & \\
\hline
\end{tabular}

We can find several points from the table above, and the mean value of long-term debt proportion is higher than the mean value of short-term debt proportion apparently. The minimum value of short-term debt proportion almost is zero. The term structure of debt financing in certain companies tends to the way of long-term financing. We can also find that the fluctuations of standard deviation of both LD and SD are steady.

The Structure of Debt Source. The contents in the table below are the structure of debt source in public companies in retail industry during 2005-2014.

Descriptive statistics a

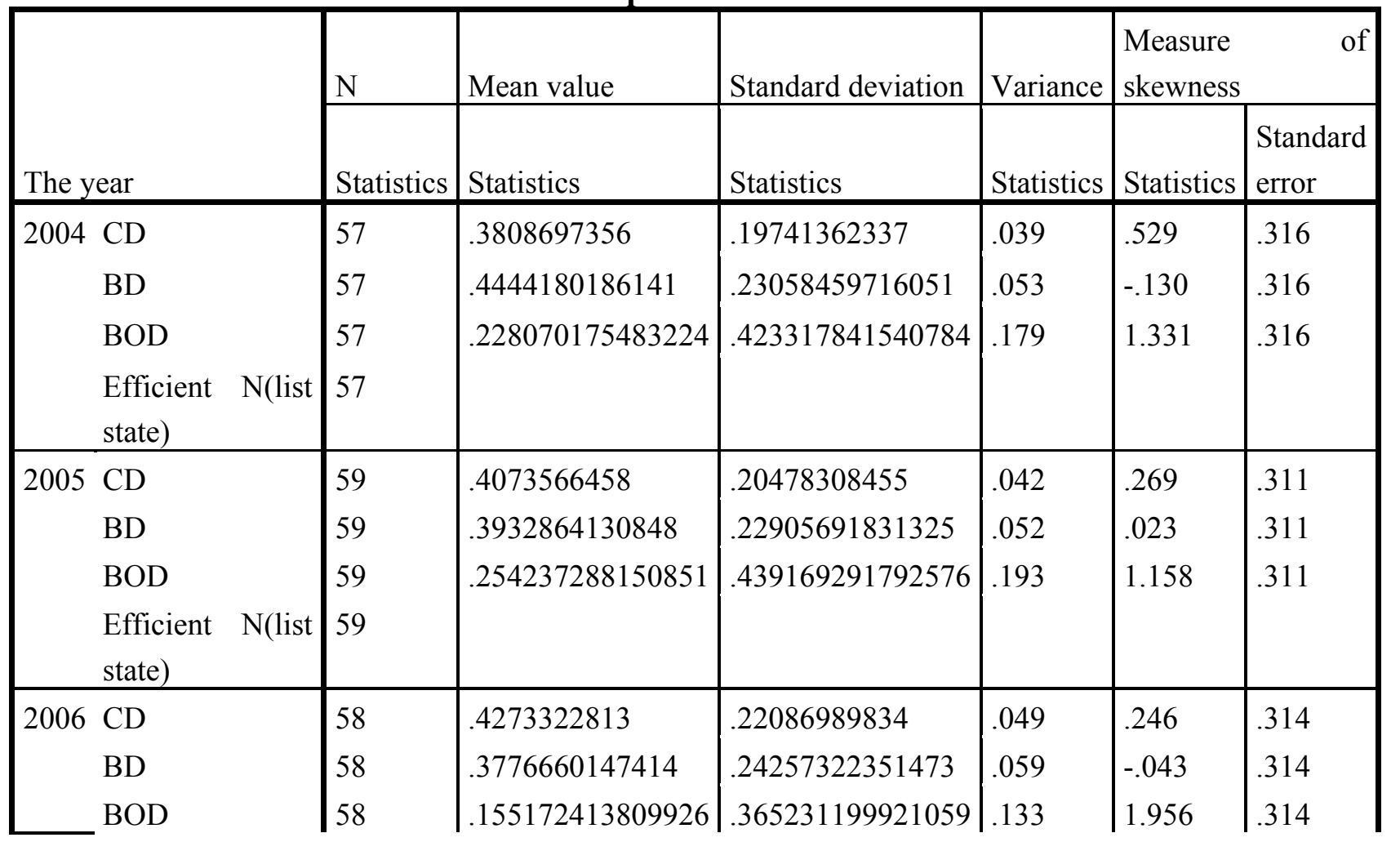




\begin{tabular}{|c|c|c|c|c|c|c|c|}
\hline & $\begin{array}{l}\text { Efficient N（list } \\
\text { state) }\end{array}$ & 58 & & & & & \\
\hline 2007 & $\begin{array}{l}\text { CD } \\
\text { BD } \\
\text { BOD } \\
\text { Efficient N (list } \\
\text { state) }\end{array}$ & $\begin{array}{l}58 \\
58 \\
58 \\
58\end{array}$ & $\begin{array}{l}.4558289513 \\
.3318649328966 \\
.112994352552725\end{array}$ & $\begin{array}{l}.21942773833 \\
.23364455184827 \\
.312489303773605\end{array}$ & $\begin{array}{l}.048 \\
.055 \\
.098\end{array}$ & $\begin{array}{l}.119 \\
.289 \\
2.501\end{array}$ & $\begin{array}{l}.314 \\
.314 \\
.314\end{array}$ \\
\hline 2008 & $\begin{array}{l}\text { CD } \\
\text { BD } \\
\text { BOD } \\
\text { Efficient N (list } \\
\text { state) }\end{array}$ & $\begin{array}{l}62 \\
62 \\
62 \\
62\end{array}$ & $\begin{array}{l}.4899705219 \\
.3032808642420 \\
.112903225846931\end{array}$ & $\begin{array}{l}.24731134462 \\
.23462118420514 \\
.319057973528223\end{array}$ & $\begin{array}{l}.061 \\
.055 \\
.102\end{array}$ & $\begin{array}{l}.074 \\
.347 \\
2.507\end{array}$ & $\begin{array}{l}.304 \\
.304 \\
.304\end{array}$ \\
\hline 2009 & $\begin{array}{l}\text { CD } \\
\text { BD } \\
\text { BOD } \\
\text { Efficient N (list } \\
\text { state) }\end{array}$ & $\begin{array}{l}65 \\
65 \\
65 \\
65\end{array}$ & $\begin{array}{l}.5278200744 \\
.2725995559847 \\
.137824564917068\end{array}$ & $\begin{array}{l}.24851881138 \\
.25061440540543 \\
.335727547408245\end{array}$ & $\begin{array}{l}.062 \\
.063 \\
.113\end{array}$ & $\begin{array}{l}-.061 \\
.595 \\
2.125\end{array}$ & $\begin{array}{l}.297 \\
.297 \\
.297\end{array}$ \\
\hline 2010 & $\begin{array}{l}\text { CD } \\
\text { BD } \\
\text { BOD } \\
\text { Efficient N (list } \\
\text { state) }\end{array}$ & $\begin{array}{l}70 \\
70 \\
70 \\
70\end{array}$ & $\begin{array}{l}.5558554523 \\
.2639189455901 \\
.134163499754126\end{array}$ & $\begin{array}{l}.24522650865 \\
.24749834451276 \\
.336138964200144\end{array}$ & $\begin{array}{l}.060 \\
.061 \\
.113\end{array}$ & $\begin{array}{l}-.234 \\
.759 \\
2.180\end{array}$ & $\begin{array}{l}.287 \\
.287 \\
.287\end{array}$ \\
\hline 2011 & $\begin{array}{l}\text { CD } \\
\text { BD } \\
\text { BOD } \\
\text { Efficient N (list } \\
\text { state) }\end{array}$ & $\begin{array}{l}77 \\
77 \\
77 \\
77\end{array}$ & $\begin{array}{l}.5493610869 \\
.2390708776754 \\
.095806323004063\end{array}$ & $\begin{array}{l}.23917354324 \\
.23324818695128 \\
.289727592099953\end{array}$ & $\begin{array}{l}.057 \\
.054 \\
.084\end{array}$ & $\begin{array}{l}-.199 \\
.734 \\
2.798\end{array}$ & $\begin{array}{l}.274 \\
.274 \\
.274\end{array}$ \\
\hline 2012 & $\begin{array}{l}\text { CD } \\
\text { BD } \\
\text { BOD } \\
\text { Efficient N (list } \\
\text { state) }\end{array}$ & $\begin{array}{l}80 \\
80 \\
80 \\
80\end{array}$ & $\begin{array}{l}.5401990855 \\
.2446240150875 \\
.070989044738254\end{array}$ & $\begin{array}{l}.24219427998 \\
.23566821816699 \\
.224439956944661\end{array}$ & $\begin{array}{l}.059 \\
.056 \\
.050\end{array}$ & $\begin{array}{l}-.083 \\
.589 \\
3.106\end{array}$ & $\begin{array}{l}.269 \\
.269 \\
.269\end{array}$ \\
\hline 2013 & $\begin{array}{l}\mathrm{CD} \\
\mathrm{BD} \\
\mathrm{BOD} \\
\text { Efficient N (list } \\
\text { state) }\end{array}$ & $\begin{array}{l}81 \\
81 \\
81 \\
81\end{array}$ & $\begin{array}{l}.5233900565 \\
.2350184592840 \\
.165676928529634\end{array}$ & $\begin{array}{l}.24099440538 \\
.22450508556262 \\
.321582086931768\end{array}$ & $\begin{array}{l}.058 \\
.050 \\
.103\end{array}$ & $\begin{array}{l}.004 \\
.528 \\
1.671\end{array}$ & $\begin{array}{l}.267 \\
.267 \\
.267\end{array}$ \\
\hline
\end{tabular}

We can find several points from the table above, and the structures of debt source in public companies in retail industry are more likely to choose the loan of commercial credit and bank loan. In the comparison, the mean value of enterprise bond proportion is lower, because the bond market in our country is not still complete, we have the serious limitation for the issuing scale, and the issuing request is higher. Analyzing from the distribution of measure of skewness, the most part distributes on the left of the mean value with skewness. 


\section{Regression Analysis.}

\begin{tabular}{|l|l|l|l|l|l|}
\hline Model & $\mathrm{R}$ & Model gather & \\
\hline 1 & $.467^{\mathrm{a}}$ & .218 & $\begin{array}{l}\text { Adjusted } \mathrm{R} \\
\text { square }\end{array}$ & $\begin{array}{l}\text { Standard estimated } \\
\text { error }\end{array}$ & Durbin-Watson \\
\hline 1
\end{tabular}

a. Predictive variable: (constant), DER, CD, BOD, SD, BD。

b. Dependent variable: ROA

Anova $^{b}$

\begin{tabular}{|c|c|c|c|c|c|c|}
\hline Model & & $\begin{array}{l}\text { Quadratic } \\
\text { sum }\end{array}$ & $\mathrm{df}$ & Mean square & $\mathrm{F}$ & Sig. \\
\hline 1 & $\begin{array}{l}\text { Regression } \\
\text { Residual } \\
\text { Aggregate }\end{array}$ & $\begin{array}{l}.404 \\
1.452 \\
1.857\end{array}$ & $\begin{array}{l}5 \\
661 \\
666\end{array}$ & $\begin{array}{l}.081 \\
.002\end{array}$ & 36.807 & $.000^{\mathrm{a}}$ \\
\hline
\end{tabular}

a. Predictive variable: (constant), DER, CD, BOD, SD, BD。

b. Dependent variable: ROA

\section{Coefficient $^{\text {a }}$}

\begin{tabular}{|c|c|c|c|c|c|c|c|c|c|c|}
\hline \multirow[b]{2}{*}{ Model } & \multicolumn{2}{|c|}{$\begin{array}{l}\text { Nonstandardize } \\
\mathrm{d} \text { coefficient }\end{array}$} & \multirow{2}{*}{$\begin{array}{l}\text { Standardiz } \\
\text { ed } \\
\text { coefficient }\end{array}$} & \multirow[b]{2}{*}{$\mathrm{t}$} & \multirow[b]{2}{*}{ Sig } & \multicolumn{3}{|c|}{ Dependency } & \multicolumn{2}{|c|}{$\begin{array}{l}\text { Collinearity } \\
\text { statistics }\end{array}$} \\
\hline & $\mathrm{B}$ & $\begin{array}{l}\text { Standardiz } \\
\text { ed error }\end{array}$ & & & & $\begin{array}{l}\text { Zero-ord } \\
\text { er }\end{array}$ & $\begin{array}{l}\text { Deflecti } \\
\text { on }\end{array}$ & $\begin{array}{l}\text { Portio } \\
n\end{array}$ & $\begin{array}{l}\text { Toleran } \\
\text { ce }\end{array}$ & VIF \\
\hline $\begin{array}{l}1 \text { (consta } \\
\text { nt) }\end{array}$ & $\begin{array}{l}.08 \\
0\end{array}$ & .011 & & $\begin{array}{l}6.97 \\
2\end{array}$ & $\begin{array}{l}.00 \\
0\end{array}$ & & & & & \\
\hline $\mathrm{SD}$ & $\begin{array}{l}-.06 \\
2\end{array}$ & .013 & -.188 & $\begin{array}{l}-4.62 \\
7\end{array}$ & $\begin{array}{l}.00 \\
0\end{array}$ & -.258 & -.177 & -.159 & .715 & $\begin{array}{l}1.39 \\
9\end{array}$ \\
\hline $\mathrm{CD}$ & $\begin{array}{l}.03 \\
9\end{array}$ & .015 & .176 & $\begin{array}{l}2.59 \\
2\end{array}$ & $\begin{array}{l}.01 \\
0\end{array}$ & .321 & .100 & .089 & .256 & $\begin{array}{l}3.89 \\
9\end{array}$ \\
\hline $\mathrm{BD}$ & $\begin{array}{l}-.04 \\
2\end{array}$ & .015 & -.195 & $\begin{array}{l}-2.88 \\
4\end{array}$ & $\begin{array}{l}.00 \\
4\end{array}$ & -.360 & -.111 & -.099 & .258 & $\begin{array}{l}3.86 \\
9\end{array}$ \\
\hline BOD & $\begin{array}{l}-.01 \\
0\end{array}$ & .005 & -.062 & $\begin{array}{l}-1.77 \\
9\end{array}$ & $\begin{array}{l}.07 \\
6\end{array}$ & .001 & -.069 & -.061 & .971 & $\begin{array}{l}1.03 \\
0\end{array}$ \\
\hline DER & $\begin{array}{l}-.00 \\
4\end{array}$ & .001 & -.162 & $\begin{array}{l}-4.09 \\
8\end{array}$ & $\begin{array}{l}.00 \\
0\end{array}$ & -.262 & -.157 & -.141 & .761 & $\begin{array}{l}1.31 \\
4\end{array}$ \\
\hline
\end{tabular}

a. Dependent variable: ROA

We can find several points from the tables above, the random distribution splashes of equation of linear regression is 1.929 , and the sum of squares of deviations is 1.857 , and the residual sum of squares is 1.452 , and regression coefficient is 0.404 . In the significance testing of regression equation, statistics $\mathrm{F}$ is 36.807 , and the corresponding confidence level is 0.000 . It is less 0.05 than the confidence level common used obviously. Therefore, this equation is significant. We can find 
from the dependency that the coefficients of association of all this variable are not zero at all, and those are relevant, and it effects the fiscal treatment of company. Inspecting by $\mathrm{T}$ the significance of coefficient, the result indicates that analyzing from the term structure of debt financing, the confidence levels of short-term debt proportion are less than 0.05 at all, and the coefficient is significant. The confidence levels of long-term debt proportion is higher. It has been deleted, and the coefficient is not more significant. We can learn from descriptive statistics that long-term debt proportion is higher than short-term debt proportion. But analyzing from the regression result analysis of debt term structure, the effects of short-term debt in company's fiscal treatment are better than long-term debt. So that it verifies the assumption one. Analyzing from the structure of debt financing source, the confidence level of enterprise bond proportion is 0.076 , and it is larger than the 0.05 common used. It is likely to be related to the non-complete of the bond market in our country. We can find from the table that the confidence level of commercial credit rate and bank borrowing rate are less than 0.05 at all. Therefore, these coefficient are significant. And the confidence level of bank borrowing rate is 0.04 , and it is less than the 0.010 of the confidence level of commercial credit rate. It indicates that bank borrowing rate has better effects in company's fiscal treatment. But we can learn from the descriptive analysis of earlier structure of debt source that the commercial credit rate of public companies in retail industry is higher than the bank borrowing rate, and it is namely that adopting the way of commercial credit to conduct debt financing. But analyzing from the regression result of the structure of debt source, the effects of bank loan in company's fiscal treatment are better than commercial credit. Therefore, it verifies the assumption two.

\section{Conclusion}

In the model of this article, all of sort-term rate, long-term rate, commercial credit rate, bank borrowing rate, enterprise bond proportion, property right proportion are closely related to the effects of company's fiscal treatment. We find from the structure of debt term that short-term debt is less than long-term debt. We get the relative conclusion from regression result, and the short-term debt has better effects in company's fiscal treatment. Enterprise tends to borrow long-term debt for decreasing repayment pressure. It deviated from the aim that balanced arranging short-term debt, medium-term debt and long-term debt in the structure of debt term, and remaining proper proportion to them, to adapt to the different capital request in production and management. Analyzing from the structure of debt source, the commercial credit rate is larger than bank borrowing rate, but according to the analysis of regression result, we find that bank loan has better effects in company's fiscal treatment, and the independence of stakeholders involved in commercial credit is the worst. Ultimately, enterprise's fiscal treatment effects is not shown fully because we do not have good supervision to enterprise. The confidence level of enterprise bond proportion is 0.076 , and it is larger than 0.05 common used. It indicates that fiscal treatment effects of enterprise bond is not more significant. The company which takes issuing enterprise bond as debt financing channel gets less at present. The bond market is still not complete at present, and it needs more development. To sum up the descriptions above, debt financing of public companies in retail industry at present does not let enterprise's fiscal treatment effects fully play its role.

\section{References}

[1] Y.Z. Er. The Example Analysis to the Effects of Debt Financing of Listed Electricity Company in Company's Performance. Master's Thesis of Anhui University. 2011.

[2] X.M. Chen. The Research on Fiscal Treatment Effects of Shanxi's Listed Coal Company. Master's Thesis of Shanxi University of Finance and Economics. 2013. 